\title{
ANALYSIS OF ROMANIAN IT INDUSTRY; STRATEGIC DIAGNOSTICS USING MICHAEL PORTER'S MODEL
}

\author{
Cătălina Florentina ALBU \\ The Bucharest University of Economic Studies, Bucharest, Romania \\ catalina.albu@man.ase.ro \\ Ștefan Cătălin POPA \\ The Bucharest University of Economic Studies, Bucharest, Romania \\ catalin.popa@man.ase.ro \\ Ana Alexandra GORA \\ The Bucharest University of Economic Studies, Bucharest, Romania \\ anaalexandra.gora@gmail.com
}

\begin{abstract}
The information technology (IT) sector represents a phenomenon of modern society, which has led to a favorable change in the economic course, in most countries of the world. This study aims to establish the attractiveness of the IT industry in Romania, as well as the factors that led to the development of the competitive environment, through a strategic diagnosis using a tool for strategic analysis and diagnosis - the model of the five forces, developed by Michael Porter. The results of the study indicate that all five strengths of Michael Porter's model exert significant influence, but in different proportions, on the competitive environment and the degree of attractiveness of the IT industry. Although Porter's model offers a clear strategic frame of the IT industry, it is quite static, and the manifestation of the five forces does not maintain its validity over time.
\end{abstract}

Keywords: analysis, competition, IT industry, Michael Porter's model, strategy.

\section{INTRODUCTION}

The information technology (IT) industry, comprising service activities in information technology and information services, is one of the most attractive and most likely to achieve significant results, both nationally and internationally. Internationally, the development of the IT industry, took place after 1958, and the connections between the economy and the IT industry, were analyzed by researchers, theorists and managers, starting with 1973. In Romania, the IT sector has undergone a spectacular development after 1990. Nowadays, Romania has a high potential to become a real force in the IT industry. 
The development of the IT sector contributes to the growth of the Gross Domestic Product (GDP), the improvement of the employees' s competences within the IT companies, the degree of innovation at the technological level, positive impact on the employment rate (ANIS, 2013). It also leads to the efficiency and dynamism of the business sectors, and to the increase of the level of education.

The IT sector is characterized by an upward evolution, as a result of the emergence of new businesses, based on the knowledge society, increasing competition in other sectors of the economy, but also as a result of new investment possibilities. Some authors (Kamel, 2005), consider that the use of IT services represents a platform for business and socioeconomic development. Nearly $100 \%$, organizations turn to IT services to eliminate business risks, protect the information system, reduce the number of business interruptions, software and hardware security, technical security services and permanent technological support. The upward evolution of the IT industry is also explained by the existence of some strengths, compared to other industries, namely: low investments, reduced launch time, no natural resources required. On the other hand, the organizations of the IT sector allocate significant financial resources for the training and improvement of the personnel.

Research carried out in the Romanian IT industry, and especially those that carry out strategic analyzes of this sector using strategic diagnostic models, are limited. General research on the IT industry, using Michael Porter's model, has been carried out (Mohapatra, 2011). Research was also carried out into the relevance of the five forces of Michael Porter's model on the innovative and ever-changing organizational environment (Brujil, 2018).

The purpose of the paper is to analyze the IT industry in Romania, using the Michael Porter's model of the five forces. This model will effectively determine the attractiveness of the IT sector in Romania, as well as the intensity with which each of the five forces contributes to the formation of the competitive framework of the Romanian IT industry. Analyzing the entire industry, each organization that carries out its activity in the IT field, will have a wider vision on the capabilities of the competitors, but also on the strategic possibilities of developing and overcoming the barriers arising from the external organizational environment.

\section{IT INDUSTRY IN ROMANIA}

Although the United States holds the most IT certifications, it faces stiff competition from attractive regions such as Romania, Ukraine and India. Internationally, Romania ranks 3rd place in Database Development and Administration, Computer Technical Support, MS SQL Server 2000 Programming and RDBMS Concepts, 4th place in DB2 Programming, Oracle PL/SQL, LAN/WAN Communications and Computer Electronics, and 5th place in Java 2 Fundamentals, Linux Administration (General), MS Windows Server 2003 Administration, MS Windows XP Desktop Administration, HTML 4.0 and Web Development 
Concepts (Brainbench, 2006). Romania's competitive position is due to its advantages held over other countries: internet speed, low costs, competent and qualified specialists.

As a result of the rapid technological development, the Romanian IT sector has become extremely dynamic and successful, thus designing the country in a particularly favorable light, in terms of growth and innovation (Nae \& Turnock, 2009). As Leon and Tabără states (2018), although the Romanian IT industry is currently one of the most prosperous industries, managing to stay for years in the forefront of the Romanian economy, it needs to develop more own products, to focus more on designing and developing its own program and to and to permanently follow the international requirements.

In Romania, an essential contribution to training and maintaining the performance in the IT field, is represented by the skilled workforce. The development of skills and training in the IT field represents a necessity for Romania's vision of a promising future in the IT industry (Grundey \& Heeks, 1998). The world's largest IT corporations consider that the IT industry in Romania is attractive, due to the low cost of labor and the high professional qualifications of the employees, but also due to the tax benefits offered by the Romanian state (Leon \& Tabără, 2018).

The internal market for software and IT services in 2017 increased by only 2.1\% compared to 2016, reaching 975 million euros. The total turnover of the IT sector increased by $11 \%$ in 2017 , compared to 2016, reaching the threshold of 4 billion euros (ANIS, 2018). Figure number 1 contain the evolution of Romanian IT Industry, in 2015-2021 period, based on predictions and real situations and, depending on two indicators: market volumes (in million EURO), and annual growth rates (in \%).

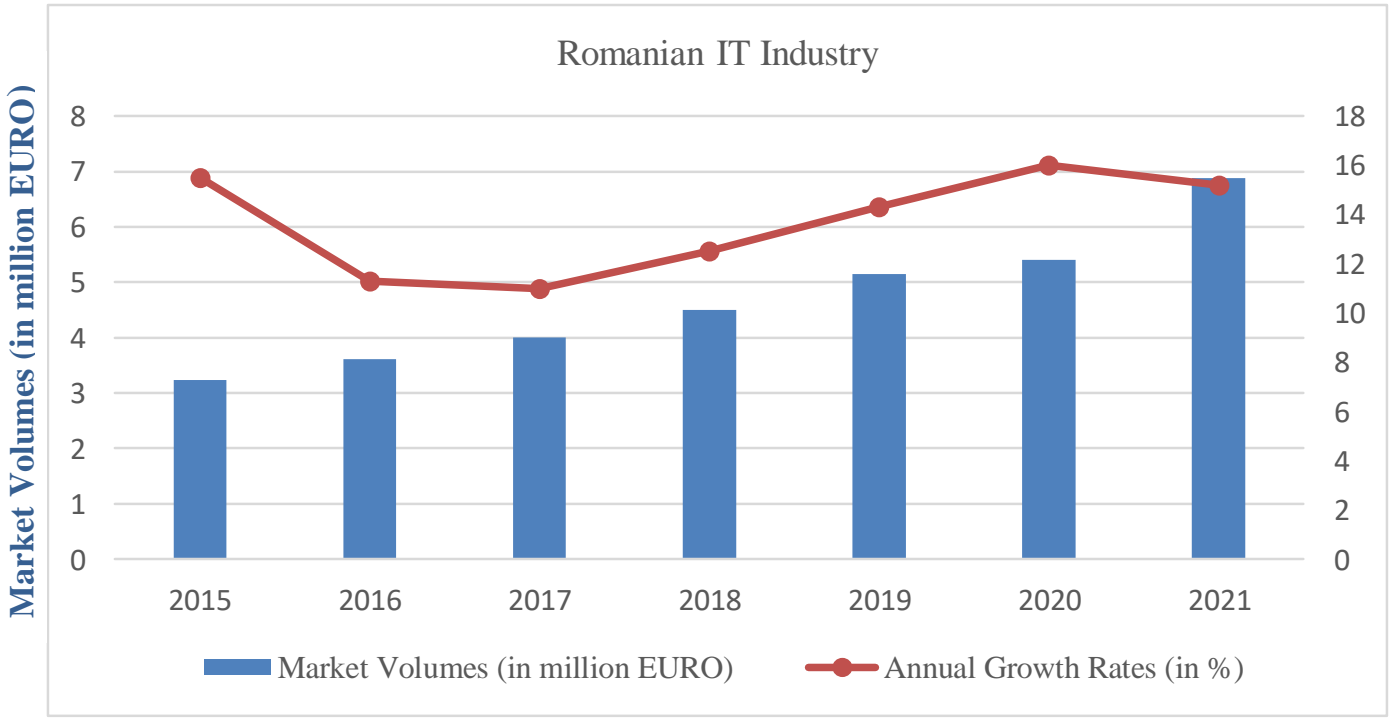

FIGURE 1. ROMANIAN IT INDUSTRY IN 2015-2021 PERIOD

Source: (ANIS, 2018) 
By analyzing the Romanian IT industry in 2015-2018 period, regarding the market volumes (market volume - the total amount of transactions observed in a specific marketplace over a specified time frame), it can be noticed the upward evolution, from 3,24 million EURO in 2015, to 4,5 million EURO in 2018. Concerning the annual growth rates for the same period, in 2015 was recorded the highest annual growth rate, namely $15,5 \%$, and in 2017 was recorded the lowest annual growth rate, namely $11 \%$. By analyzing the predictions for 2019-2021 period, specialists consider the market volumes will be in a continuous growth, as in the previous period, reaching a value of 6,88 million EURO market volume in 2021. Although annual growth rates increase from year to year, it is expected that in 2021 , it will reach $15,2 \%$, with $0,3 \%$ less that the annual growth rate registered in 2015.

\section{MICHAEL PORTER'S MODEL}

Professor Michael Porter is considered one of the most important authorities in the world regarding the competitiveness, the competitive strategy in the business organizations and in the application of the competitive analysis in the social and environmental aspects of the business activities (Snowdon \& Stonehouse, 2006). Michael Porter (1979), addressing the problem of competitive forces within an industry, has developed a dynamic model, known and widely used in both theory and managerial practice. By taking into account the competitive forces, the organization can develop more efficient strategies, which can lead to the improvement of the competitive position. The goal of Michael Porter's model is to understand the "underpinnings of competition and the root causes of profitability" (Porter, 2008, p. 29). Michael Porter (1985) argues that an organization, by analyzing the five forces, can develop a competitive strategy. In this way, the organization may be able to offer superior performances through an adequate configuration and at the same time, through an efficient coordination of activities.

According to some authors (Grundy, 2006; Stonehouse \& Snowdon, 2007) Porter's model is a very static model, which diminishes its usefulness, but it can but it can be given a dynamic perspective. Michael Porter's model is a powerful and helpful tool in the hands of a skilled manager or analyst. However, its application raises some difficulties, especially as a result of the fact that practical ideas that can contribute to the application of the model in real organizational situations, have not been developed (Dobbs, 2014). The five competitive forces elaborated by Porter, M., are presented in figure no. 2. 


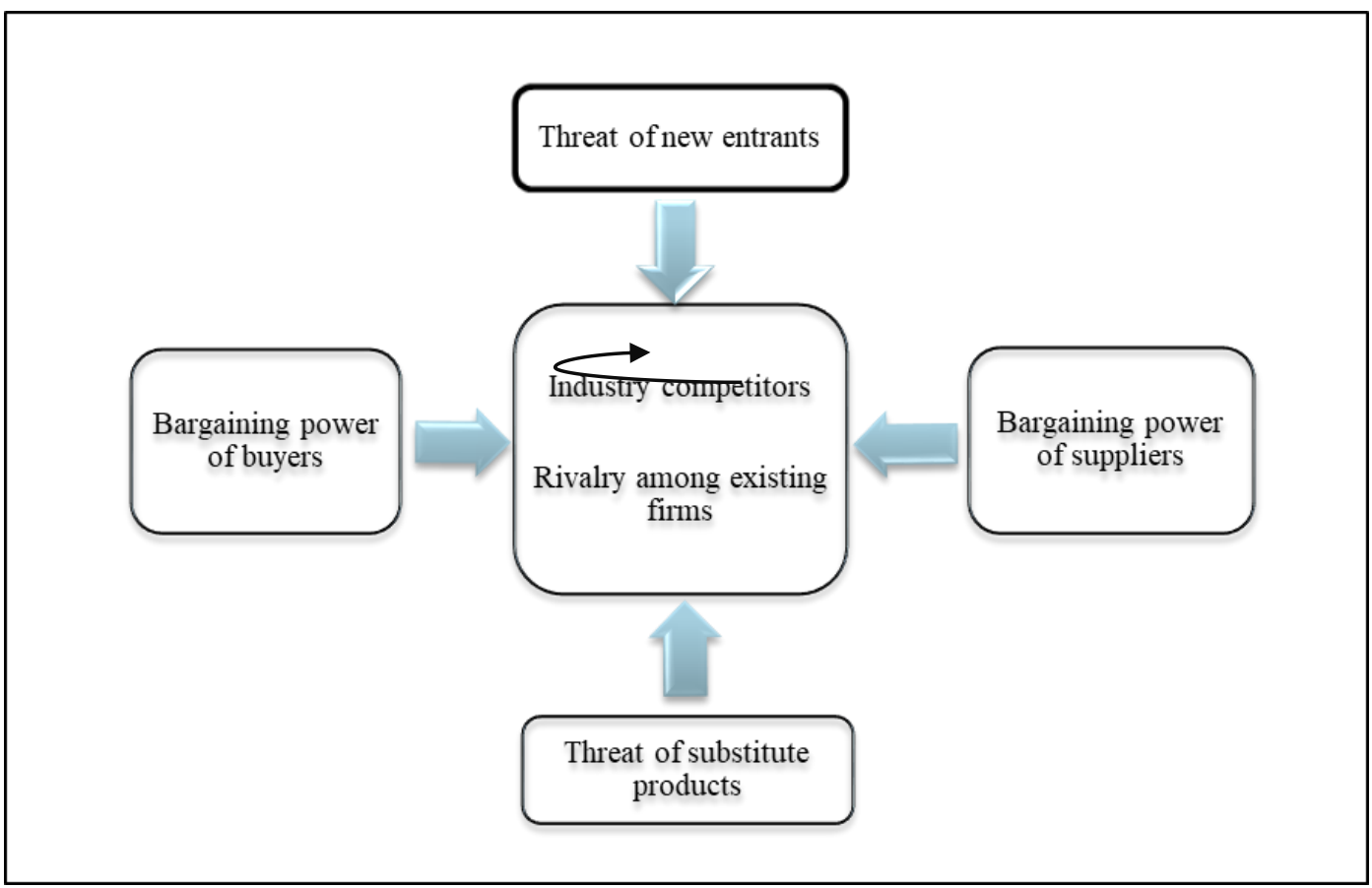

FIGURE 2. MICHAEL PORTER'S MODEL

Source: adapted by authors after (Porter, 1979)

\subsection{Threats of new entrants in Romanian IT industry}

New competitors can appear at any time within the IT industry in Romania, so it is necessary that this probability be permanently analyzed within the IT organizations. If the number of competitors increases within an industry, the intensity of competition will be atrocious.

New entrants in Romanian IT industry can threaten existing companies through economies of scale. Thus, new companies can obtain lower costs from the entry on the market, compared to the costs of existing companies, by the existence of a higher number of IT services. Some of these services may be innovative, as a result of research on international IT industries, and taking over the latest information, especially those related to operating systems and information security. The economy of scale represents, in fact, a strategy of the new entrants, through which they obtain a competitive advantage from the entrance to the market, which consists in the differentiation by costs / the advantage by costs. New companies in the IT industry can pose a threat to existing companies, approaching many other strategies, which can differentiate themselves from the competition, from a significant point of view: superior quality of services, conquering new markets and low prices.

Although new entrants may in some cases generate a decrease in the performance of existing companies, they also have disadvantages, primarily related to the lack of experience in the market. Moreover, new entrants to the IT sector must bear the costs of entering the market. Although the costs of entry into the IT 
industry are significantly lower than the costs of entry into other industries, they still exist. As a result of the lack of experience, newcomers to the IT industry don't know the effects of external environment factors and haven't knowledge in change management. Usually, the clients of the IT companies tend to permanentize the services offered by the suppliers, so that, for the newly created IT companies, it becomes more difficult to create and develop a stable circle of clients.

\subsection{Bargaining power of buyers in Romanian IT industry}

The bargaining power of the customers is a powerful force in any IT sector, as the final consumers influence the price of the products, thus, the profitability of the sector can be affected. As a result of several possible options, customers are constantly comparing products / services, having a strong bargaining influence on the value for money. Customers of IT services have a high sensitivity to price changes.

The volume of clients calling for IT services in Romania is increasing from one period to another, as a result of the continuous improvement of the IT industry and the permanent need to adapt the clients to the demands imposed by the changes in the fields of data and information. The clients of the IT services are first of all the big companies that need Network support, IT service management, data protection, guarantee of security and software solutions that guarantee a detailed organization of the hardware and software infrastructure. Other clients of IT services are users of mobile phones, TVs and cars, and even educational institutions.

The bargaining power of the clients increases with the development of the IT industry, both at the level of Romania and internationally. Thus, this factor significantly influences the price of IT services, as a result of multiple choice possibilities. Customers have permanent access to information on the price and quality of IT service suppliers, so they can easily make comparisons. Moreover, the emergence of new companies in the IT industry, can lead to changes in the preferences of customers, who have never changed their option before.

\subsection{Bargaining power of suppliers in Romanian IT industry}

When there are a small number of potential suppliers for certain products, suppliers have high bargaining power, and as a result, prices may be affected. For some IT companies, changing the provider may be an impediment, due to limited alternatives, but also to the costs associated with this change.

Some of the IT service providers in Romania are represented by international companies that have designed operating systems, programming and scripting languages, and other information programs. The bargaining power of the suppliers is significant in the IT industry, as some products / services of the suppliers cannot be easily replaced. However, besides providing imperative services, some companies in the IT industry in Romania "provide" their own products, which consist of programs tailored to the needs of 
clients. For companies that have specialized personnel in this field and permanently innovate, by creating services, the bargaining power of the suppliers is not a force that can lead to the change of the competitive position.

\subsection{Threat of substitute products in Romanian IT industry}

Although companies can have a competitive advantage for a period, as a result of the existence of innovative products on the market, there is always the risk of the appearance of products that can accurately mimic the original product. The substitute product has a lower price and satisfies almost equally the requirements of the customers, and as a result it can easily be transformed into the consumer's choice Although IT services cannot be easily replaced, some customers, because of the high prices, especially the newly established companies, may prefer that the IT services be provided on their own, by using free computer software. Obviously, these programs do not provide the same quality functions, as the programs provided by specialized companies, but they provide support to companies that wish to distribute financial resources for other purposes.

The possibility of occurrence of substitution products is a force that is constantly manifested in the IT sector in Romania. The evolution of technology and the knowledge-based society lead to the establishment of new companies in the IT field. These companies can provide information services and information technology services that can easily replace existing services.

\subsection{Rivalry among existing firms in Romanian IT industry}

Competition within an industry is the strongest force that can affect the performance of an organization. This force refers to the number of competitors existing in a sector, but also to the diversity, prices and quality of competing products.

Approximately 17,000 companies operate in the Romanian IT industry. The most intense competition is manifested in the eight strongest companies in Romania, presented in table number 1.

TABLE 1.THE EIGHT MOST POWERFUL COMPANIES IN THE ROMANIAN IT SECTOR

\begin{tabular}{|c|c|c|}
\hline IT COMPANY & LOCATION & $\begin{array}{c}\text { FISCAL VALUE IN 2017 } \\
\text { (MILLION EURO) }\end{array}$ \\
\hline BITDEFENDER & BUCHAREST & 129,6 \\
\hline UIPATH & BUCHAREST \\
\hline SOFTVISION & CLUJ-NAPOCA & 42,9 \\
\hline NET BRINEL & CLUJ-NAPOCA & 34 \\
\hline
\end{tabular}


Albu C. F., Popa Ş. C., Gora A. A.

ANALYSIS OF ROMANIAN IT INDUSTRY; STRATEGIC DIAGNOSTICS USING MICHAEL PORTER'S MODEL

\begin{tabular}{|c|c|c|}
\hline AROBS & CLUJ-NAPOCA & 27,1 \\
\hline FORTECH & CLUJ-NAPOCA & 24,0 \\
\hline QUALITANCE & BUCHAREST & 10 \\
\hline TERMEND & BUCHAREST & 10 \\
\hline
\end{tabular}

Source: adapted by authors after (Loghin, A., 2018)

It is expected that in the next 14 years, the number of IT specialists in Romania will increase 4 times, thus reaching 400,000 people, under the conditions of an annual growth rate of 10\% in the IT sector (Nița \& Mihalache, 2018). This increase will be due to the continuous development of existing IT organizations, but also to the emergence of a new company, and will intensify the rivalry between existing companies. Rivalry among existing firms in Romanian IT industry it also appears as a result of qualitative differences in information services. The intense rivalry within the Romanian IT companies is manifested within the wellknown brands (such as those identified in table number 1 ), considered by the customers to be the most powerful and able to satisfy the most demanding demands. Although, in general, the life of a product I service comprises four phases (launch, growth, maturity and decline), the search for IT services extends their life, thus intensifying the rivalry between existing companies.

\section{CONCLUSION}

Internationally, IT industry has led to the economic evolution and development of the information society and knowledge. The IT industry is one of the most important industries in the world, which contributes significantly to improving the financial indicators that characterize the economic power of countries, such as gross domestic product and unemployment rate.

Studying the IT industry in Romania, from a strategic point of view, is of particular importance as a result of ranking this industry in one of the most prosperous in the country. It is very important to maintain the current rate of growth by adopting measures that further stimulate its development. Considering the strengths of Michael Porter's model as being essential in the strategic analysis of the competitive environment that characterizes the IT industry in Romania, it started from the assumptions that this model offers a clear and complete picture of the most profitable companies in the Romanian IT sector. According to Michael Porter's model, the best-positioned companies are those that belong to the industries in which the five forces manifest with less importance.

Analyzing the impact of the five forces of Michael Porter's model on the Romanian IT industry, it can be said that all five forces exert a significant influence, but in different proportions. The risk of the emergence of new companies in the IT industry will exist permanently, as a result of the expansion of the markets that 
require a large number of such services. As a result of the increasing number of companies in the IT sector, the rivalry will continue to place in the first places only those organizations that manage to differentiate strategically, through innovation and the ability to win important parts of the market. In most sectors of Romania, including in the IT sector, the bargaining power of buyers will significantly influence the competitive position of companies. As a result of the specific characteristics of the Romanian IT services companies, the bargaining power of the suppliers and the threat of substitute products, don't manifest as strongly as the other forces. The Romanian IT companies in which these two forces don't exist, or exist without significant implications, represent the most profitable companies in the IT industry of Romania.

The strategic analysis of the IT industry in Romania based only on the five forces of Michael Porter's model, is a limitation of this study, since in identifying the economic situation of the IT sector it must be taken into account to weigh all the external organizational factors, with the major influence on the position on market.

\section{REFERENCES}

ANIS. (2018). Software \& IT Services in Romania - 2018 Edition. [Online] Available at: https://www.itstudy.anis.ro/wp-content/uploads/2018/10/ANIS-Study-2018-excerpt.pdf [Accessed 12 June 2019].

Brainbench. (2006). Global Skills Report. Talent in the 21st Century. [Online] Available https://www.brainbench.com/static/pdf/globalskills/Brainbench_GlobalSkillsReport2006.pdf [Accessed 6 June 2019].

Brujil, G. H. T. (2018). The Relevance of Porter's Five Forces in Today's Innovative and Changing Business Environment. SSRN Electronic Journal. 7 June: 1-22.

Dobbs, M. E. (2014). Guidelines for applying Porter's five forces framework: a set of industry analysis templates. Competitiveness Review. 24(1): 32-45. doi:10.1108/CR-06-2013-0059.

Grundey, M. \& Heeks, R. (1998). Romania's Hardware and Software Industry; Building IT Policy and Capabilities in a Transitional Economy. Manchester: Institute for Development Policy and Management.

Grundy, T. (2006). Rethinking and reinventing Michael Porter's five forces model. Strategic Change. 15(5): 213-229. doi:10.1002/jsc.764.

Kamel, S. (2005). The use of information technology to transform the banking sector in developing nations. Information Technology for Development. 11(4): 305-312. doi:10.1002/itdj.20023.

Leon, D. \& Tabără, N. (2018). IT Industry and its Role in the Economic Development of Romania. The 13th International Conference European Integration Realities and Perspectives. 211-217. 
Loghin, A. (2018). Top eight IT companies in Romania. [Online] Available at: http://cluju.ro/top-8-companii-it-din-romania-patru-dintre-ele-sunt-din-cluj/ [Accessed 14 June 2019].

Mohapatra, S. (2011). IT and Porter's Competitive Forces Model and Strategies. In: Information System Theory. Integrated Series and Information Systems. New York: Springer. 265-281.

Nae, M. M. \& Turnock, D. (2009). Romania's revolution in telecommunications and information technology: A geographical approach. Human Geographies. 3(2): 49-78.

Niță, I. \& Mihalache, G. (2018). The Romanian IT industry will reach 400,000 employees in the next 14 years.

Available at: http://zf.ro/business-hi-tech/zf-digital-2018-industria-it-din-romania-va-ajunge-la-400000-de-angajati-in-urmatorii-14-ani-17559395, [Accessed 16 June 2019].

Porter, M. E. (1979). How Competitive Forces Shape Strategy. Harvard Business Review. 52(2): 137145.

Porter, M. E. (2008). The five competitive forces that shape strategy. Harvard Business Review. 86(1): 25-40.

Porter, M. E. (1985). Competitive advantage: Creating and sustaining superior performance. New York: Free Press.

Snowdon, B. \& Stonehouse, G. (2006). Competitiveness in a globalized world: Michael Porter on the microeconomic foundations of the competitiveness of nations, regions, and firms. Journal of International Business Studies. 37(2): 163-175.

Stonehouse, G. \& Snowdon, G. (2007). Competitive Advantage Revisited: Michael Porter on Strategy and Competitiveness. Journal of Management Inquiry. 16(3): 256-273. doi:10.1177/1056492607306333. 